\title{
Job Satisfaction Level Of Government Employees: The General Directorate Of Sport And Sports Federations Sample
}

\author{
Murat Kalfa, PhD \\ Dilek Tufan \\ Gazi University, Sports Management Department, Turkey \\ Merve Karaman \\ Gazi University, Recreation Department, Turkey \\ doi: 10.19044/esj.2016.v12n2p32 URL:http://dx.doi.org/10.19044/esj.2016.v12n2p32
}

\begin{abstract}
The purpose of this study is to determine the job satisfaction levels of employees of sports federation and general directorate of sport, and to analyze according to some variables. "Minnesota Job Satisfaction Questionnaire" was used to determine the job satisfaction levels of employees. Since the data didn't fulfill the parametric assumptions, nonparametric Kruskall-Wallis and Man-Whitney U tests were used on the analysis according to job satisfaction levels. According to results of analysis, $98.8 \%$ of employees' job satisfaction levels are medium and high. It was revealed that there is a statistically significant difference between employees' general job satisfaction, internal and external sub-dimension points according to age groups, marital status, situation of selecting their jobs willingly and educational level. As a result; it was seen in terms of general job satisfaction and internal satisfaction that internal satisfaction levels of employees who are 40 or more in comparison with employees who are between 22-40 age groups, internal satisfaction levels of employees whose marital status are married in comparison with employees whose marital status are single, general satisfaction and internal satisfaction levels of employees who selected their job willingly and general, internal and external satisfaction levels of employees whose education levels are associate degree in comparison with employees whose education levels are bachelor's degree and postgraduate are higher.
\end{abstract}

Keywords: Sport Management, Job Satisfaction, Government Employee, Public Officer, Public Servant 


\section{Introduction}

Modern management science adopted the idea that the most important source for institutions to reach the success and to maintain this success is the source of "human" and in this direction the concept of the concept of job satisfaction gained importance. Evaluating the job satisfaction of employees through questionnaires have started to become popular since 1930s (Latham \& Budworth, 2007). In plenty of studies carried out in organizational behavior and social sciences fields, it was figured out that there is a positive correlation between job satisfaction and job performance (Malik, 2011; Rehman \& Waheed, 2011).

Job satisfaction are defined as an emotional reaction that employee created by evaluating his/her job and job environment and also revealing the job satisfaction or dissatisfaction by interacting individual's requirements and experiences with job satisfaction. As a result of accumulation of knowledge and sense such as happiness and sadness that individual sees, experiences and obtains throughout his/her working life, attitude towards their jobs or business are formed. And job satisfaction forms the general structure of this attitude (Rue \& Byars, 1995). According to Luthan, since job satisfaction is an emotional response for a job situation, it is invisible and it is just expressed, represents various attitudes related with each other such as to what extent it satisfies the expectation, job itself, price, possibilities of promotion, way of management, workmates, the need of recognition (Luthans, 1989). Job satisfaction is formed by internal reactions developed to perceptions related to job and working conditions made by getting through the individual's system of norms, values, expectations. People can show mainly to their jobs one of three different orientations "job-oriented, careeroriented and passion-oriented” (Heslin, 2005).

Job satisfaction is a situation which shouldn't be forgotten that it is a dynamic phenomenon. Namely, providing job satisfaction doesn't mean that this situation will last constantly. For this reason, job satisfaction is a phenomenon that must always be watched at regular intervals. It is thought that this study will contribute to determine the job satisfaction of employees of General Directorate of Sport and Sport Federations which are Turkey central sport management organizations.

As a result of these, the purpose of this study is to determine the job satisfaction levels of employees of sports federation and general directorate of sport, and to analyze according to some variables. For this purpose, an answer for the question of “do the job satisfaction levels of employees of General Directorate of Sport and Sport Federations display difference according to some variables” is sought. 


\section{Methodology \\ Participants}

Population involves employees of sports federation and general directorate of sport. And research sample consists of 105 female and 142 male wanting to take part in study voluntarily whose age averages are $40.53 \pm 9.86$ and in total there are 247 employees.

\section{Instruments}

The form that was used as a data collection tool in study is composed of two categories. First category is composed of the questions towards collecting the demographic informations of employees, and in second category Minnesota Job Satisfaction Questionnaire developed by Weiss, Dawis, England and Lofquist in 1967 to determine the job satisfaction levels of employees. Validity and reliability studies were carried out by adopting into Turkish by Baycan (1985). Minnesota Job Satisfaction Questionnaire is a five item Likert scale with items answered on a 1-5 point scale. MSQ is the abbreviation and is composed of 20 questions and each question has 5 options. 1 to 5 points were given respectively to evaluate the options of "Totally Not Satisfied", "Not Satisfied”, "Neutral”, "Satisfied” and "Totally Satisfied". Accordingly the highest point that can be obtained in questionnaire is 100, the lowest is 20. 25 and under point indicates low, points amidst 26-74 indicates medium, 75 and above indicates high satisfaction. As a result of reliability analysis carried out for this study, internal consistency coefficient of questionnaire (Croanbach Alpha) was found to be .95 .

\section{Statistical Analyses}

To reveal the demographic characteristics of employees and job satisfaction levels, frequency and percentage distributions were carried out. The distributions of variables were examined according to groups; when evaluating the normality of distribution and homogeneity of variance, MannWhitney $U$ test was carried out to analyze the differences according to gender, age, marital status, worked institution, situation of selecting the job willingly, situations of taking education in-service and quality in-service because parametric assumptions weren't fulfilled, and Kruskal-Wallis H test was used to compare educational levels according to their jobs.

\section{Results}

When analyzed the job satisfaction levels of employees, it is seen that $61.1 \%$ of employees have medium job satisfaction level, $37.7 \%$ of employees have high job satisfaction level. In the direction of this finding, it can be said that employees of sports federation and general directorate of 
sport have medium-high job satisfaction levels. It wasn't found that there is difference among job satisfaction points according to only employees' age groups, marital statuses, educational levels, situations of selecting their jobs willingly (Table 1; Table 2; Table 3; Table 4).

Table 1. Comparison of job satisfaction points of employees according to their ages

\begin{tabular}{|c|c|c|c|c|c|c|c|}
\hline & Age & $\mathrm{N}$ & $\begin{array}{l}\text { Mean } \\
\text { Rank }\end{array}$ & Mean Sum & $\mathrm{U}$ & $\mathrm{z}$ & $\mathrm{p}$ \\
\hline \multirow{2}{*}{$\begin{array}{c}\text { Internal } \\
\text { Satisfaction }\end{array}$} & $22-40$ & 128 & 107,91 & 13812,50 & 5556,500 & $\begin{array}{c}- \\
3,674\end{array}$ &, $000 *$ \\
\hline & $\begin{array}{l}40 \text { and } \\
\text { above }\end{array}$ & 119 & 141,31 & 16815,50 & & & \\
\hline \multirow{2}{*}{$\begin{array}{c}\text { External } \\
\text { Satisfaction }\end{array}$} & $22-40$ & 128 & 116,02 & 14850,00 & 6594,000 & $\begin{array}{c}- \\
1,823\end{array}$ & ,068 \\
\hline & $\begin{array}{c}40 \text { and } \\
\text { above }\end{array}$ & 119 & 132,59 & 15778,00 & & & \\
\hline \multirow{2}{*}{$\begin{array}{c}\text { General } \\
\text { Satisfaction }\end{array}$} & $22-40$ & 128 & 110,79 & 14181,50 & 5925,500 & $\begin{array}{c}- \\
3,014\end{array}$ & ,003* \\
\hline & $\begin{array}{l}40 \text { and } \\
\text { above }\end{array}$ & 119 & 138,21 & 16446,50 & & & \\
\hline
\end{tabular}

According to results of Mann-Whitney U test carried out to determine the employees' general job satisfaction and sub-dimension points according to age groups; while statistically significant difference among the external sub-dimension points of respondents who are in age range of 22-40 and 40 and above wasn't found [(247)=1.406; $\mathrm{p}>0.05]$, in terms of general satisfaction $[(247)=1.406 ; \mathrm{p}<0.05]$ and internal satisfaction $[(247)=1.406$; $\mathrm{p}<0.05$ ] job satisfaction levels of employees who are 40 and above are higher than employees whose ages between 22-40 (Table 1).

Table 2. Comparison of Job Satisfaction Points of Employees According to Their Marital Status

\begin{tabular}{|c|c|c|c|c|c|c|c|}
\hline & $\begin{array}{l}\text { Marital } \\
\text { Status }\end{array}$ & $\mathrm{N}$ & $\begin{array}{l}\text { Mean } \\
\text { Rank }\end{array}$ & Mean Sum & U & $\mathrm{z}$ & $\mathrm{p}$ \\
\hline \multirow{2}{*}{$\begin{array}{c}\text { Internal } \\
\text { Satisfaction }\end{array}$} & Married & 172 & 130,26 & & \multirow[t]{2}{*}{5373,000} & \multirow[t]{2}{*}{$\begin{array}{c}- \\
2,088\end{array}$} & \multirow[t]{2}{*}{,037* } \\
\hline & Single & 75 & 109,64 & 8223,00 & & & \\
\hline \multirow{2}{*}{$\begin{array}{c}\text { External } \\
\text { Satisfaction }\end{array}$} & Married & 172 & 129,12 & 22208,50 & \multirow[t]{2}{*}{5569,500} & \multirow[t]{2}{*}{$\begin{array}{c}- \\
1,707\end{array}$} & \multirow[t]{2}{*}{,088 } \\
\hline & Single & 75 & 112,26 & 8419,50 & & & \\
\hline \multirow{2}{*}{$\begin{array}{c}\text { General } \\
\text { Satisfaction }\end{array}$} & Married & 172 & 129,81 & 22327,00 & \multirow[t]{2}{*}{5451,000} & \multirow[t]{2}{*}{$\begin{array}{c}- \\
1,936\end{array}$} & \multirow[t]{2}{*}{,053 } \\
\hline & Single & 75 & 110,68 & 8301,00 & & & \\
\hline
\end{tabular}

According to results of Mann-Whitney U test carried out to determine the employees' general job satisfaction according to age groups; statistically significant difference between general satisfaction [(247)=1.936; $\mathrm{p}>0.05$ ] 
and external satisfaction [(247)=1.707; p >0.05] points of respondents wasn't found. When considered the internal satisfaction points which is one of subdimensions of job satisfaction, job satisfaction levels of employees who are married in comparison with employees who are single are higher $[(247)=2.088 ; \mathrm{p}<0.05$; Table 2].

Table 3. Comparison of Job Satisfaction Points of Employees According to Their Educational Levels

\begin{tabular}{|c|c|c|c|c|c|c|}
\hline & Educational Level & $\mathrm{N}$ & $\begin{array}{l}\text { Mean } \\
\text { Rank }\end{array}$ & sd & $x^{2}$ & $\mathrm{p}$ \\
\hline \multirow{4}{*}{$\begin{array}{c}\text { Internal } \\
\text { Satisfaction }\end{array}$} & $\begin{array}{l}\text { High School and } \\
\text { under }\end{array}$ & 41 & 129,55 & \multirow[t]{4}{*}{3} & \multirow[t]{4}{*}{9,397} & \multirow[t]{4}{*}{,024* } \\
\hline & Associate & 34 & 153,94 & & & \\
\hline & Bachelor's Degree & 148 & 119,35 & & & \\
\hline & Postgraduate & 24 & 100,77 & & & \\
\hline \multirow{4}{*}{$\begin{array}{c}\text { External } \\
\text { Satisfaction }\end{array}$} & $\begin{array}{l}\text { High School and } \\
\text { under }\end{array}$ & 41 & 125,27 & \multirow[t]{4}{*}{3} & \multirow[t]{4}{*}{9,267} & \multirow[t]{4}{*}{,026* } \\
\hline & Associate & 34 & 156,57 & & & \\
\hline & Bachelor's Degree & 148 & 119,01 & & & \\
\hline & Postgraduate & 24 & 106,46 & & & \\
\hline \multirow{4}{*}{$\begin{array}{c}\text { General } \\
\text { Satisfaction }\end{array}$} & $\begin{array}{l}\text { High School and } \\
\text { under }\end{array}$ & 41 & 127,38 & \multirow[t]{4}{*}{3} & \multirow[t]{4}{*}{11,129} & \multirow[t]{4}{*}{,011* } \\
\hline & Associate & 34 & 158,24 & & & \\
\hline & Bachelor's Degree & 148 & 118,92 & & & \\
\hline & Postgraduate & 24 & 101,06 & & & \\
\hline
\end{tabular}

According to results of Kruskal-Wallis $\mathrm{H}$ test carried out to determine the job satisfaction points of employees according to educational levels; general satisfaction[X2(3)=11.129; $\quad \mathrm{p}>0.05]$, internal satisfaction $[\mathrm{X} 2(3)=9.397 ; \mathrm{p}>0.05]$ and external satisfaction [X2(3)=9.267; $\mathrm{p}>0.05]$ don't become different (Table 3). According to Mann-Whitney U tests carried out to reveal in which groups this difference originates, job satisfaction of employees whose educational levels are associate degree in comparison with employees whose educational levels are bachelor's degree and postgraduate are higher.

Table 4. Comparison of Job Satisfaction Points of Employees According to Situation of Choosing the Job Voluntarily

\begin{tabular}{cccccccc}
\hline & $\begin{array}{c}\text { Choosing } \\
\text { the Job } \\
\text { Voluntarily }\end{array}$ & $\mathrm{N}$ & Mean Rank & Mean Sum & $\mathrm{U}$ & $\mathrm{z}$ & $\mathrm{p}$ \\
\hline Internal & Yes & 194 & 131,56 & 25522,00 & 3675,000 & $-3,183$ &, $001^{*}$ \\
Satisfaction & No & 53 & 96,34 & 5106,00 & & & \\
External & Yes & 194 & 130,98 & 25410,00 & 3787,000 & $-2,940$ &, $003^{*}$ \\
Satisfaction & No & 53 & 98,45 & 5218,00 & & & \\
General & Yes & 194 & 131,62 & 25535,00 & 3662,000 & $-3,210$ &, $001^{*}$ \\
Satisfaction & No & 53 & 96,09 & 5093,00 & & & \\
\hline
\end{tabular}


According to results of Mann-Whitney U test carried out to determine the employees' job satisfaction levels according to situation of selecting their jobs willingly; there is a statistically significant difference between the general satisfaction [(247) $=3.210 ; \mathrm{p}<0.05]$ and internal satisfaction $[(247)=3.183 ; \mathrm{p}<0.05]$ points of employees who say that they selected the job willingly and who say that they didn't select the job willingly (Table 4).

\section{Discussion and Conclusion}

Within the research, job satisfaction levels of employees of general directorate of sport and sport federations were examined and it was figured out that general job satisfaction is at medium-high level. In the study carried out by Kalay, Arslan and Oflas (2013) in which job satisfaction of nonphysician allied health personnel was examined, it was determined that job satisfaction is low. In various studies conducted in different government institutions, it was determined that job satisfaction levels are at medium level (Günbayı, 2000; Koç, Yazıcığlu \& Hatipoğlu, 2009; Yılmaz, 2012; Altınkurt \& Y1lmaz, 2014). At levels of job satisfaction according to gender, significant difference between job satisfaction points and internal and external job satisfactions which are sub-dimensions wasn't found. In literature, job satisfaction levels didn't display difference according to gender and there are studies that show parallelism with this research (Kurçer, 2005; Ibn Rahman \& Parveen, 2008; Tözün, Çulhacı \& Ünsal, 2008; Ward \& Sloane, 2000; Türkçapar, 2012; Yazıc1 \& Altun, 2013; Özmutlu, Tekin, Yüksek, Mutlu \& Eraslan, 2013; Yeşilyurt \& Koçak, 2014). However; there are studies, results of which don't match up with ours (Tack \& Patitu, 1992; Özdevecioğlu, 2003; Hult, Callister \& Sullivan, 2005; Liu \& Ramsay; 2008).

Significant difference between general job satisfaction points and internal and external job satisfactions, which are sub-dimensions, of employees of General Directorate of Sport and Sport Federations according to worked institutions; worker, civil servant, chef, assistant expert, departmental manager and senior managers according to their jobs; employees who take education and don't take education according to situation of taking education in-service; employees who take education and don't take education according to situation of taking education quality inservice wasn't found. According to age groups it was figured out that in terms of general job satisfaction and internal satisfaction employees who are 40 and above have higher job satisfaction levels than employees whose age ranges are among 22-40. In Yelboğa's study (2007) showing parallelism with research results, it was concluded that 41 and above age groups get more job satisfaction than 31-40 age groups. Even though there are studies (Bilge et al., 2007; Toker, 2007; Faris \& Berg, 2010; Lui \& et al, 2011; Kalay, Arslan \& Oflas, 2013) that support this result, there are also studies 
showing that age variable doesn't affect the job satisfaction (Keser, 2005; Tözün, Çulhacı \& Ünsal, 2008; Can, Soyer \& Yılmaz, 2010; Türkçapar, 2012; Kargün, Albay, Cenikli \& Güllü, 2012; Yeşilyurt \& Koçak, 2014).

In the relationship between levels of job satisfaction and marital status variable, statistically significant difference between general and external satisfaction points of married and single employees wasn't found. Also when examined the internal satisfaction points which is one of the sub-dimensions of job satisfaction, job satisfaction levels of married employees in comparison with single employees are higher. Also in the study conducted by Kargün, Albay, Cenikli and Güllü (2012), it was revealed that married referees' job satisfaction sensuality values are higher than single referees. However, this difference isn't statistically significant $(\mathrm{p}>0.05)$. In addition, in plenty of studies it was determined that job satisfaction level couldn't be correlated with marital status (Blegen, 1993; Bilgiç, 1998; Toker, 2007; Tözün, Çulhacı \& Ünsal, 2008; Abdel-Rahman and his friends, 2008; Türkçapar, 2012; Kalay, Arslan \& Oflas, 2013; Yeşilyurt \& Koçak, 2014).

When considered the job satisfaction levels according to educational level, it was determined that general, internal and external satisfactions of employees whose educational level is bachelor's degree are higher than employees with postgraduate and associate degree. It was determined that in Kayıkçı's study (2005) job satisfaction levels of employees with master and doctor's degree are lower than other groups. Also in literature, beside researches which reveal that there is a relationship between educational level and job satisfaction (Toker, 2007: 103), there are a lot of researches that reveal this relationship doesn't exist (Bilgiç, 1998; Piyal, Çelen \& Şahin, 2000; Adams and Bond, 2000; Öztürk \& Deniz, 2008; Can, Soyer \& Y1lmaz, 2010; Rehman \& Vaheed, 2011; Lui et al., 2011; Türkçapar, 2012; Özmutlu, Tekin, Yüksek, Mutlu \& Eraslan, 2013; Kalay, Arslan \& Oflas, 2013; Yeşilyurt \& Koçak; 2014). According to job satisfaction levels' situation of selecting the job willingly, statistically significant difference between general and internal satisfaction points wasn't found. Türkçapar (2012) figured out that job satisfaction points of Physical Education Teachers don't change according to situation of selecting the job willingly. As a result, it was seen that there is a difference between job satisfaction points according to respondents' age groups, marital status, educational levels situation of selecting the job willingly.

\section{References:}

Abdel-Rahman A. G., Meky, F., Abdel-Halim, A. W .E., \& Alam, M. F. (2008). Low Job Satisfaction Among Physicians İn Egypt. TAF Prev MEd Bull, 7(2), 91-6. 
Adams, A. \& Bond, S. (2000). Hospital nurses' job satisfaction, individual and organizational characteristics. Journal of Advanced Nursing, 32 (3), 536-543.

Altınkurt, Y. \& Yılmaz, K. (2014). Öğretmenlerin Mesleki Profesyonelliği İle İş Doyumları Arasındaki İlişki. Sakarya University Journal of Education, 4/2, ss. 57-71.

Baycan, A. (1985). An Analysis of the Several Aspects of JobSatisfaction between different Occupational Groups. PhDDissettation. Boğaziçi Üniversitesi Sosyal Bilimler Enstitüsü, İstanbul.

Bilge, F., Akman, Y. \& Kelecioğlu, H. (2007). Öğretim Elemanlarının İş Doyumlarının İncelenmesi. Hacettepe Üniversitesi Eğitim Fakültesi Dergisi, 32, 32-41.

Bilgiç, R. (1998). The relationship between job satisfaction and personal characteristics of Turkish workers. The Journal of Psychology, 132 (5), 549557.

Blegen \& Mary A. (1992). Nurses' Job Satisfaction: A Meta-Analysis of Related Variables. Nursing Research, 42(1), 36-41.

Can, Y., Soyer \& F. Yılmaz, (2010). F. Hentbol Hakemlerinin İş Doyumu ve Mesleki Tükenmişlik Düzeyleri Arasındaki İlişkinin İncelenmesi, Selçuk Üniversitesi Beden Eğitimi ve Spor Bilimi Dergisi, 12(2);113-119.

Faris, Judith A., Berg \& Laurie R. (2010). Job satisfaction of advanced practice nurses in the Veterans Health Administration. Journal of the American Academy of Nurse Practitioners, 22, 35-44.

Günbayı, İ. (2000). Örgütlerde İş Doyumu ve Güdülenme. Ankara: Özen Yayımcilik.

Heslin A. P. (2005), “Experiencing Career Success”, Organizational Dynamics, Vol, 34 (4), ss, 376-390

Hult, C., Callister, R. R. \& Sullivan, K. (2005). Is there a global warming toward women in academia. Liberal Education, 91, 50-57.

Ibn Rahman, M. \& Parveen, R. (2008). Job Satisfaction: A study among public and private university teachers of Bangladesh. Journal of ICMAB, 34, 73-90.

Kalay, F., Arslan, H.\& Oflas, Ş. (2013). Kadrolu ve 4/B Sözleşmeli Yardımcı Sağlık Personellerinin İş Doyumlarının Karşılaştırılması. Selçuk Üniversitesi Sosyal Bilimler Enstitüsü Dergisi, 29.

Kargün, M., Albay, F., Cenikli, A. \& Güllü, M. (2012). Türk Futbol Hakemlerinin İş Doyumu Ve Mesleki Tükenmişlik Düzeylerinin İncelenmesi. Spor ve Performans Araştırmaları Dergisi, 3, 2, 30-38.

Kayıkçı, K. (2005). Milli Eğitim Bakanlığı Müfettişlerinin Denetim Sisteminin Yapısal Sorunlarına İlişkin Algıları Ve İş Doyum Düzeyleri. Kuram ve Uygulamada Eğitim Yönetimi, 44, 507-527. 
Keser, A. (2005). The relationship between job and life satisfaction in automobile sector employees in Bursa Turkey. İş Güç Endüstri İlişkileri ve İnsan Kaynakları Dergisi, 7(2).

Koç, H., Yazıcıoğlu, İ. \& Hatipoğlu, H. (2009). Öğretmenlerin İş Doyum Algıları İle Performansları Arasındaki İlişkinin Belirlenmesine Yönelik Bir Araştırma. Ondokuz Mayıs Üniversitesi Eğitim Fakültesi Dergisi, 28, 13-22.

Kurçer, M. A. (2005). Harran Üniversitesi tıp fakültesi hekimlerinin iş doyumu ve tükenmişlik düzeyleri. Harran Üniversitesi Tıp Fakültesi Dergisi, 2, 10-15.

Latham, G. P. \& Budworth, M. H. (2007). The study of work motivation in the 20th century. In L. L. Koppes (Ed.) Historical perspectives in industrial and organizational psychology (pp. 353-381). Mahwah, NJ: Lawrence Erlbaum

Liu, Cicely S., Pharm, B. \& White, L. (2011). Key determinants of hospital pharmacy staff's job satisfaction. Research in Social and Administrative Pharmacy, 7, 51-63.

Liu, X. S. \& Ramsey, J. (2008). Teachers' job satisfaction: Analyses of the teacher follow-up survey in the United States for 2000-2001. Teaching and Teacher Education, 24, 1173-1184.

Luthans, F. (1989). Organizational Behavior. McGraw-Hill

Malik, N. (2011). "Study On Job Satisfaction Factors Of Faculty Members At Unıversity Of Balochistan”, Internatıonal Journal Of Academic Research, 3(1), 267-272.

Özdevecioğlu, M. (2003). İş Tatmini Ve Yaşam Tatmini Arasındaki İlişkinin Belirlenmesine Yönelik Bir Araştırma. 11. Ulusal Yönetim ve Organizasyon Kongresi, 22-24, Afyon, Türkiye.

Özmutlu, İ., Tekin, M., Yüksek, S., Mutlu, T.O. \& Eraslan, M. (2013). An analysis on the job satisfactions levels of soccer referees. Turkish Journal of Sport and Exercise, 15,1, 31_36.

Öztürk, A. \& Deniz, M. E. (2008). Okul Öncesi Öğretmenlerinin Duygusal Zekâ Yetenekleri İş Doyumları ve Tükenmişlik Düzeylerinin Bazı Değişkenler Açısından İncelenmesi. İlköğretim Online, 7(3), 578-599.

Piyal, B., Çelen, Ü., Sahin, N. \& Piyal, B. (2000). Ankara Üniversitesi Tıp Fakültesi Hastanesinde Çalışanların İş Doyumu. Ankara Üniversitesi Tıp Fakültesi Mecmuas1, 53(4), 241-250.

Rehman, M. S. \& Waheed, A. (2011). An Empirical Study Of Impact Of Job Satisfaction On Job Performance In The Public Sector Organizations. Interdisciplinary Journal Of Contemporary Research In Business, 2(9), 167181.

Rue L. W. \& L. L. Byars, (1995), Management:Skills and Applications, Chicago, Irwin 
Tack, M. W. \& Patitu, C. L. (1992). Faculty job satisfaction: Women and minorities in peril. ASHE-ERIC higher education report no. 4. Washington, DC: Association for the study of higher education.

Toker, B. (2007). Demografik Değişkenlerin İş Tatminine Etkileri: İzmir'deki Beş Ve Dört Yıldızlı Otellere Yönelik Bir Uygulama. Doğuş Üniversitesi Dergisi, 8 (1), 92-107.

Tözün, M., Çulhacı, A. \& Ünsal, A. (2008). Aile hekimliği sisteminde birinci basamak sağlık kurumlarında çalışan hekimlerin iş doyumu (Eskişehir). TAF Prev Med Bull, 7(5), 377-384.

Türkçapar, Ü. (2012). Beden Eğitimi Öğretmenlerinin Farklı Değişkenler Açısından İş Doyumu Düzeylerinin İncelenmesi. GEFAD / GUJGEF 32 (2): 331-346.

Ward, M. E. \& Sloane, P. J. (2000). Non-pecuniary advantages versus pecuniary disadvantages: Job satisfaction among male and female academics in Scottish universities. Scottish Journal of Political Economy, 47, 273-303.

Weiss, D. J., Dawis, R. V., England, G. W., \& Lofquist, L. H. (1967). Manual of the Minnesota Satisfaction Questionnaire. Minneapolis: MN: The University of Minnesota Press.

Yazıcı, H. \& Altun, F., (2013). A Tipi Kişilik, Cinsiyet ve İş Doyumu: Üniversite Öğretim Elemanları Üzerinde Bir Araştırma. Kuram ve Uygulamada Eğitim Bilimleri, 13(3), 1447-1459.

Yelboğa, A. (2007). Bireysel demografik değişkenlerin iş doyumu ile ilişkisinin finans sektöründe incelenmesi. Çağ Üniversitesi Sosyal Bilimler Dergisi, 4(2), 1- 19.

Yeşilyurt, H. \& Koçak, N. (2014). İş Doyumu ve Örgütsel Vatandaşl1k Davranışı Arasındaki İlişkinin Otel İşletmeleri Açısından İncelenmesi. Dokuz Eylül Üniversitesi Sosyal Bilimler Enstitüsü Dergisi. Cilt: 16, Sayı: 2, s: 303-324.

Yılmaz, K. (2012). İlköğretim Okulu Öğretmenlerinin İş Doyumu Düzeyleri İle Örgütsel Vatandaşlık Davranışları Arasındaki İlişki. Anadolu Journal of Educational Sciences International, 2 (2), 1-14. 